\title{
PENGARUH PENYULUHAN ANTISIPASI BABY BOOMING ERA PANDEMI BAGI BIDAN PUSKESMAS KOTA BANJARMASIN
}

\author{
Renny Aditya, Samuel Tobing \\ Divisi Obstetri \& Ginekologi Sosial Fakultas Kedokteran ULM RSUD Ulin Banjarmasin \\ rennyaditya@gmail.com
}

\begin{abstract}
Abstrak
Coronavirus disease 2019 (Covid-19) adalah penyakit yang sedang mewabah hampir di seluruh dunia saat ini, dengan nama virus Severe Acute Respiratory Syndrome Coronavirus-2 (Sars-Cov2). Penyakit ini pertama kali dilaporkan pada 31 Desember 2019. Pada ibu usia reproduksi ini tentunya menjadi perhatian khusus sebagai dampak adanya Pandemi ini, terdapat angka drop-out yang meningkat dan supply kontrasepsi terdapat angka penurunan yang signifikan. Pandemi Covid-19 telah berdampak terhadap baby boom atau "ledakan bayi". Menurut laporan Badan Kependudukan dan Keluarga Berencana Nasional (BKKBN) pada Mei 2020 ada lebih dari 400.000 kehamilan tak direncanakan. Masyarakat sulit mengakses alat kontrasepsi karena selama dilangsungkannya Pembatasan Sosial Berskala Besar (PSBB), sejumlah klinik kesehatan dan kandungan ditutup. Prediksi terdapat lebih dari 420.000 bayi baru lahir. Perkiraan angka tersebut didasarkan pada 10 persen dari 28 juta keluarga yang mengalami kesulitan dalam mengontrol kelahiran. Penelitian ini bertujuan untuk mengetahui pengaruh penyuluhan yang dilakukan melalui daring tentang antisipasi baby booming bagi Bidan di Puskesmas Kota Banjarmasin. Penelitian ini merupakan penelitian pra-eksperimental dengan pendekatan one group pretest-posttest design. Besar sampel penelitian adalah 50 orang dengan teknik pengambilan proportional stratified random sampling. Penyuluhan dilakuna dengan metode ceramah via aplikasi zoom dengan link yang di share 1 minggu sebelumnya. Analisis data menggunakan uji Wilcoxon dan t berpasangan. Hasil penelitian ini menunjukkan setelah penyuluhan tentang antisipasi baby booming era pandemi Covid-19 terdapat peningkatan pengetahuan ( $\mathrm{p}$ value $=0,0001)$ dan sikap $(p$ value $=0,045)$
\end{abstract}

Kata-kata kunci: covid-19, baby booming, penyuluhan, kontrasepsi,

\section{PENDAHULUAN}

Coronavirus disease 2019 (Covid-19) adalah penyakit yang sedang mewabah hampir di seluruh dunia saat ini, dengan nama virus Severe Acute Respiratory Syndrome Coronavirus-2 (SARSCOV2). Pada ibu usia reproduksi ini tentunya menjadi perhatian khusus sebagai dampak adanya Pandemi ini, terdapat angka drop-out yang meningkat dan supply kontrasepsi terdapat angka penurunan yang signifikan. ${ }^{1,2}$ Menurut laporan Badan Kependudukan dan Keluarga Berencana Nasional (BKKBN) pada Mei 2020 ada lebih dari 400.000 kehamilan tak direncanakan. Masyarakat sulit mengakses alat kontrasepsi karena selama dilangsungkannya Pembatasan Sosial Berskala Besar (PSBB), sejumlah klinik kesehatan dan kandungan ditutup. Penambahan angka kehamilan tersebut berpotensi mengakibatkan baby boom di awal tahun depan. Prediksi terdapat lebih dari 420.000 bayi baru lahir. Perkiraan angka tersebut didasarkan pada 10 persen dari 28 juta keluarga yang mengalami kesulitan dalam mengontrol kelahiran. ${ }^{3,4,5}$

Peserta KB aktif terus meningkat setiap bulannya menurut BKKBN. Namun, sejak terjadinya pandemi Covid-19 peserta KB aktif terjadi penurunan. Bulan April terjadi penurunan peserta atau akseptor aktif $28 \%$ dibanding bulan sebelumnya. April tercatat hanya ada sekitar 26 juta peserta KB aktif padahal pada bulan Maret terdapat 36 juta 
akseptor. ${ }^{5,6}$ Pada data Maret terjadi penurunan penggunaan alat kontrasepsi disbanding dengan Februari. Kepala BKKBN Hasto Wardoyo mengungkapkan, pada Maret 2020, penggunaan semua jenis alat kontrasepsi mengalami penurunan dibanding Februari 2020. Bahkan pemakaian suntik $\mathrm{KB}$ yang paling diminati juga turun. ${ }^{7,8}$

Penambahan angka kelahiran akan menjadi masalah baru tekait kependudukan bagi negara Indonesia. Munculnya kasus Baby Boom selama pandemi Covid-19 di Indonesia akan membawa dampak yang serius dan perlu penanganan yang intens. Dampak yang akan terjadi mulai dari meningkatnya resiko kematian ibu dan anak, malnutrisi pada ibu hamil dan janin, bayi rawan terlahir prematur dan rasa tidak bertanggung jawab dari orang tua karena anak tidak diinginkan kelahirannya. Dampak tersebut secara langsung akan menciptakan permasalahan baru di Indonesia, seperti meningkatnya angka kemiskinan karena pertumbuhan penduduk. ${ }^{9,10}$

Menurut data statistik rutin nasional BKKBN, cakupan penuh KB IUD Provinsi DIY pada bulan Januari hingga Maret 2020 rata-rata adalah 2598 akseptor, sedangkan gambaran data $75 \%$ pada April 2020 menunjukkan hanya ada 422 akseptor, terjadi penurunan yang sangat besar. Strategi lainnya adalah dengan memberdayakan peran Bidan sebagai penyuluh KB/Petugas Lapangan KB untuk berperan aktif dalam penggerakan pelayanan $\mathrm{KB}$ pada masa pandemi Covid-19. ${ }^{7,8}$

Penelitian ini bertujuan untuk mengetahui pengaruh penyuluhan yang dilakukan melalui daring tentang antisipasi baby booming bagi bidan di Puskesmas Kota Banjarmasin.

\section{METODE}

Peyuluhan diselenggarakan dengan metode ceramah via aplikasi zoom $®$ dengan link yang di share 1 minggu sebelumnya. Responden diminta secara online untuk bergabung dalam pertemuan dalam aplikasi melalui undangan link Zoom® meeting, kemudian dikirmkan pretest, materi kontrasepsi penyuluhan antisipasi baby booming era pandemi Covid19 dan posttest, kemudian dilanjutkan penelitian praeksperimental dengan pendekatan one group pretestposttest design. Populasi adalah bidan aktif di cakupan wilayah kerja Puskesmas di kota Banjarmasin. Sampel adalah bidan terpilih sesuai kriteria inklusi dengan teknik purposive sampling. Sampel terdiri atas 50 responden. Kriteria Inklusi yaitu bidan yang aktif melakukan pelayanan kesehatan berupa pelayanan dan penyuluhan kontrasepsi baik berpraktik secara mandiri maupun di institusi Kesehatan serta Bersedia mengikuti kegiatan penelitian yang ditetapkan dan bersedia mengisi kuesioner pretest dan posttest. Analisis data menggunakan uji Wilcoxon dan t berpasangan.

\section{HASIL DAN PEMBAHASAN}

\section{A. Analisis Univariat}

Responden diberikan pretest dan post test dengan hasil sebagai berikut :

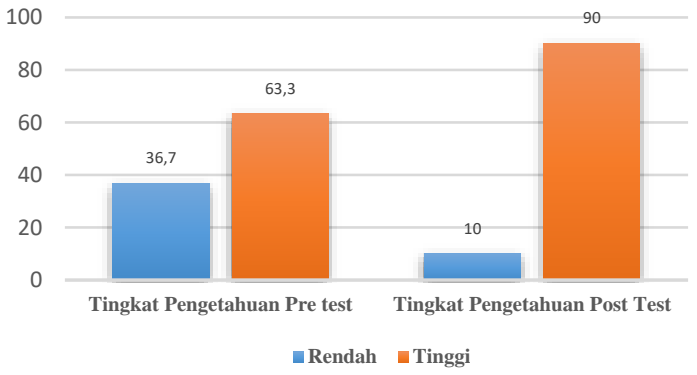

Gambar 1. Gambaran Tingkat Pengetahuan Responden Pada Pre Test dan Postest

Pada gambar 1 diketahui bahwa tingkat pengetahuan responden pada saat pre test yaitu sebanyak $36,7 \%$ responden berpengetahuan rendah dan $63,3 \%$ responden berpengetahuan tinggi dan setelah intervensi penyuluhan antisipasi baby booming era pandemi Covid-19 terjadi peningkatan pengetahuan yaitu pengetahuan tinggi menjadi $90 \%$ responden dan pengetahuan rendah berkurang jadi $10 \%$ responden. 


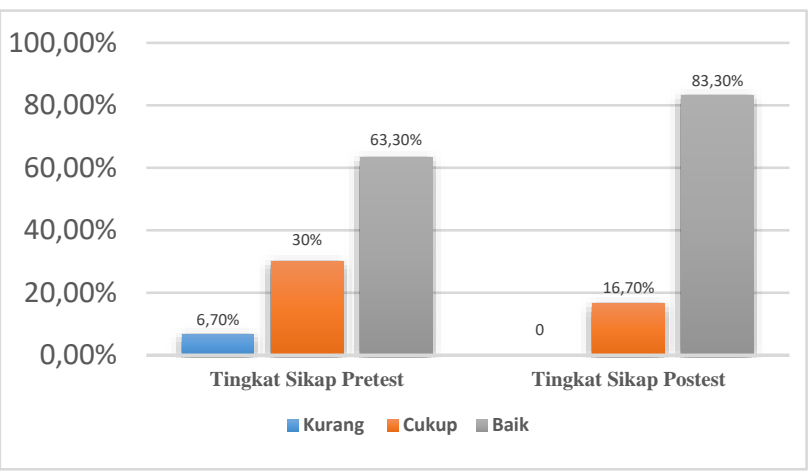

Gambar 2. Tingkat Sikap Responden pada saat pretest dan postest

Berdasarkan gambar 2 diketahui pada saat sebelum penyuluhan antisipasi baby booming era pandemi Covid-19 adalah 6,7\% responden bersikap kurang, 30\% responden bersikap cukup dan 63,3\% responden bersikap baik. Setelah dilakukan pelatihan terjadi peningkatan sikap responden mengenai antisipasi baby booming yaitu $16,7 \%$ responden bersikap cukup dan $83,3 \%$ responden mempunyai sikap yang baik.

Hasil dari pretest dan postest pengetahuan dan sikap menunjukkan bahwa penyuluhan antisipasi baby booming era pandemi Covid-19 berhasil mengubah pengetahuan dan sikap responden menjadi baik.

\section{B. Analisis Bivariat}

1. Perbedaan Pengetahuan Sebelum dan Sesudah penyuluhan antisipasi baby booming era pandemi Covid-19

Hasil nalisis dengan uji paired t test menunjukkan hasil sebagai pada tabel 1.1 yaitu :

Tabel 1.1 Hasil Analisis Pengetahuan Responden Sebelum dan Sesudah Intervensi penyuluhan

\begin{tabular}{c|l|c|c|c}
\hline No & Variabel & Mean & $\boldsymbol{p}$-value & Ket \\
\hline 1 & Pre test & 6,10 & 0,0001 & $\begin{array}{c}\text { Terdapat } \\
\text { perbedaan } \\
\text { yang } \\
\text { signifikan }\end{array}$ \\
\hline 2 & Post test & 7,53 & & \\
\hline
\end{tabular}

Berdasarkan tabel 1.1 diketahui rata-rata pengetahuan responden sebelum penyuluhan antisipasi baby booming era pandemi Covid-19 sebesar 6,10 dan setelah mendapatkan intervensi ratarata pengetahuan responden meningkat menjadi 7,53. Hasil uji paired t test menunjukkan nilai $p$-value 0,0001 artinya terdapat perbedaan yang sangat siginifikan pengetahuan sebelum dan sesudah penyuluhan tentang Baby Booming era pandemic Covid-19

\section{Perbedaan Sikap Sebelum dan Sesudah penyuluhan antisipasi baby booming era pandemi Covid-19}

Hasil analisis sikap responden dengan uji paired t test menunjukkan hasil sebagai pada Tabel 1.2 yaitu :

Tabel 1.2 Hasil Analisis Sikap Responden Sebelum dan Sesudah Intervensi penyuluhan

\begin{tabular}{c|l|c|c|c}
\hline No & Variabel & Mean & $\boldsymbol{p}$-value & Ket \\
\hline 1 & Pre test & 37,50 & 0,045 & $\begin{array}{c}\text { Terdapat } \\
\text { perbedaan yang } \\
\text { signifikan }\end{array}$ \\
\hline 2 & Post test & 41,13 & & \\
\hline
\end{tabular}

Berdasarkan tabel 1.2 diketahui rata-rata sikap responden sebelum penyuluhan antisipasi baby booming era pandemi Covid-19 sebesar 37,50 dan setelah mendapatkan intervensi rata-rata sikap responden meningkat menjadi 41,13. Hasil uji paired $t$ test menunjukkan nilai p-value 0,045 artinya terdapat perbedaan yang siginifikan pengetahuan sebelum dan sesudah intervensi penyuluhan.

Setelah dilakukan penyuluhan mengenai antisipasi maka para bidan lebih mengetahu tentang upaya pencegahan drop out kontrasepsi, Strategi yang dilakukan BKKBN dalam mempertahankan target capaian CPR (cegah putus rantai) antara lain dengan menjalankan pelayanan $\mathrm{KB}$ di Faskes namun tidak dilakukan secara masal, akseptor yang ingin ber-KB ke Faskes dilakukan penjadwalan oleh bidan di FKTP dengan mengatur jarak Pelayanan $\mathrm{KB}$, membentuk Whastapp Group (WAG) kader KB untuk sharing informasi program $\mathrm{KB}$ dan pelayanan $\mathrm{KB}$ untuk memantau kesertaan ber-KB, memberdayakan WAG yang dimiliki kader KB (grup Alumni, grup Arisan, grup pengajian dan lain-lain) untuk KIE perorangan

$$
\text { Kesehatan } 276
$$


program KB. Bagi Akseptor yang takut untuk ber-KB di faskes dilakukan konseling secara personal oleh bidan/PKB/PLKB/Kader dengan memperhatikan Social Distancing dan Physical Distancing untuk dapat dilayani. ${ }^{11,12}$

Para bidan juga di berikan panduan pelayanan $\mathrm{KB}$ pada masa adaptasi baru misalnya memberikan himbauan bagi pasangan usia subur, yaitu : ${ }^{13,14}$

- Bagi PUS yang menunda kehamilan atau tidak ingin hamil lagi harus menggunakan alat atau obat kontrasepsi

- Akseptor KB jika hendak datang mencari layanan $\mathrm{KB}$, membuat perjanjian atau melakukan tele registrasi sebelum datang ke fasilitas Kesehatan untuk mendapatkan kepastian jam layanan.

- Bagi akseptor AKDR/Implan/suntik yang sudah habis masa pakainya atau akseptor baru, jika tidak memungkinkan untuk datang ke petugas Kesehatan dapat menggunakan kondom yang dapat diperoleh dengan menghubungi petugas PLKB atau kader melalui telepon. Apabila tidak tersedia bias menggunakan cara tradisional (pantang berkala atau senggama terputus).

- Jika ada keluhan terkait penggunaan alat atau obat kontrasepsi, konsultasikan kepada petugas kesehatan lewat wa/telepon atau datang ke bidan dengan perjanjian untuk mendapatkan anjuran selanjutnya;

- Menerapkan prinsip umum pencegahan penularan COVID-19 pada saat datang ke fasilitas Kesehatan untuk mendapatkan pelayanan $\mathrm{KB}$

- Bagi Akseptor yang positif covid atau dengan status covid19 lainnya, konsultasikan kondisi kesehatan dan tidak dianjurkan melakukan hubungan seks selama masa ini sehingga penggunaan kontrasepsi dapat ditunda dan langsung dilakukan setelah sembuh atau selesai masa pemantauan;

Selain itu bidan juga di berikan penyuluhan tentang rekomendasi bagi bidan dalam melakukan pelayanan KB, yaitu dengan cara : Mengupayakan ketersediaan Tele registrasi sehingga dapat dilakukan skrining untuk memastikan bahwa klien yang datang tidak mempunyai risiko menderita Covid-19 sebelum tiba di fasilitas kesehatan dan menyampaikan pesan-pesan untuk mencegah penularan Covid19. ${ }^{15}$

- Tersedianya media KIE atau pesan-pesan kesehatan tentang pencegahan penularan Covid-19

- Petugas Kesehatan mengoptimalkan Pemberian Materi Komunikasi, Informasi dan Edukasi (KIE) serta pelaksanaan konseling terkait kesehatan reproduksi dan KB secara online atau konsultasi via telepon.

- Bidan pemberi pelayanan KB melakukan pemberian KIE dapat diberikan dengan mengoptimalkan penggunaan media online (WA, Telepon, Aplikasi smart phone, dsb), jika akan melakukan penyuluhan secara langsung harus dilakukan dengan jumlah yang terbatas dan melakukan protokol pencegahan penularan Covid-19. Optimalisasi pencatatan dan pemantauan akseptor serta berkoordinasi untuk memastikan tidak terjadi putus pakai dimasa pandemi dan melakukan pelayanan sesuai protokol kesehatan. ${ }^{14,15}$

Setelah dilakukan post test terdapat hasil yang signifikan berbeda setelah dilakukan penyuluhan penyuluhan antisipasi baby booming era pandemi Covid-19 yang sangat penting untuk mencegah peningkatan angka drop out $\mathrm{KB}$ dan pencegahan baby booming.

\section{KESIMPULAN}

1. Hasil pre-test dan post test menunjukkan terjadinya peningkatan pengetahuan responden mengenai antisipasi baby booming era pandemi Covid-19.

2. Penyuluhan antisipasi baby booming era pandemi meningkatkan sikap dan pengetahuan bidan menjadi menjadi baik dalam antisipasi mencegah terjadinya baby boom 


\section{REFERENSI}

1. Rekomendasi Penanganan Infeksi Virus Corona (COVID-19) Pada Maternal (Hamil, Bersalin, dan Nifas). Pokja Infeksi Saluran Reproduksi Perkumpulan Obstetri Dan Ginekologi Indonesia, 2020

2. Tawfik Amin T. Covid-19 and The Expected Baby Boom. Journal of Cairo University. 2020: 1-4.

3. Lebih dari 400.000 Kehamilan Baru Terjadi Selama Pandemi di Indonesia[Internet]. Kompas. 2020 [cited 30 Juli 2020]. Available from : https://www.kompas.com/sains/read/2020/05/20/ 110300923/lebih-dari-400.000-kehamilan-baruterjadi-selama-pandemi-di-indonesia?page=all.

4. Direktorat Jenderal Pencegahan dan Pengendalian Penyakit. Pedoman Kesiapsiagaan Menghadapi Coronavirus Disease (COVID-19) Maret 2020. Jakarta: Kementerian Kesehatan Republik Indonesia; 2020.

5. Arentz M, Yim E, Klaff L, et al. Characteristics and Outcomes of 21 Critically Ill Patients With COVID-19 in Washington State. JAMA. 2020.

6. World Health Organization. Laboratory testing for coronavirus disease 2019 (COVID-19) in suspected human cases. Geneva: World Health Organization; 2020.

7. Covid-19 fuelling mother and child mortality rates[Internet]. India News. 2020 [cited 3

Agustus 2020]. Available from: https://www.hindustantimes.com/indianews/Covid-19-fuelling-mother-and-childmortality-rates/storyAlGlGzVDystpDDrCUwfnbM.html.

8. BKKBN menghitung potensi kehamilan di masa pandemi Covid-19 capai 500.000[Internet]. Kesehatan Kontan. 2020 [cited 3 Agustus 2020]. Available from:

https://kesehatan.kontan.co.id/news/wow-bkkbnmenghitung-potensi-kehamilan-di-masapandemi-Covid-19-capai-500000?page $=$ all .

9. Pandemi dan penggunaan alat kontrasepsi[Internet]. Harian Nasioanal. 2020 [cited 3 Agustus 2020]. Available from: http://www.harnas.co/2020/05/04/pandemi-danpenggunaan-kontrasepsi.
10. Kusuma U, Joko A, Itriyati F. Waspadai Baby Boom Pasca Pandemi Covid-19. Fakultas Kedokteran Universitas Gadjah Mada. Yogyakarta; 2020.

11. Antisipasi Baby Boom pasca Pandemi Covid-19 [Internet]. BKKBN. 2020 [cited 3 Agustus 2020]. Available from: https://www.bkkbn.go.id/detailpost/antisipasibaby-boom-pasca-pandemi-Covid-19-bkkbnjalankan-pelayanan-kb-dengan-tetap-menjagajarak-dan-konseling-melalui-media-online.

12. BKKBN antisipasi ledakan angka kelahiran saat pandemic Covid-19[Internet]. Kabar24. 2020 [cited 3 Agustus 2020]. Available from: https://kabar24.bisnis.com/read/20200503/15/12 35673/bkkbn-antisipasi ledakan-angkakelahiran-saat-pandemi-Covid-19.

13. BKKBN laksanakan gerakan cegah putuspakai pemakaian kontrasepsi[Internet]. Mata Banua. 2020 [cited 3 Agustus 2020]. Available from:https://matabanua.co.id/2020/04/14/bkkbn -laksanakan-gerakan-cegah-putuspakaipemakaian-kontrasepsi/.

14. Kemenkes RI. Panduan pelayanan keluarga berencana dalam masa pandemi Covid-19 dan adaptasi kebiasaan baru. BKKBN. 2020.

15. Dampak Covid-19 terhadap keluarga berencana, kesehatan ibu, dan kekerasan berbasis gender[Internet]. BKKBN. 2020 [cited 3 Agustus 2020]. Available from:https://www.bkkbn.go.id/detailpost/dampa k-Covid-19-terhadap keluarga-berencanakesehatan-ibu-dan-kekerasan-berbasis-gender. 